\title{
Sublethal application of various sulfonylurea and imidazolinone herbicides favors outcrossing and hybrid seed production in oilseed rape
}

\author{
Cheng-Yu Yu* (D), Jing-long Lian, Qiong Gong, Li-Suo Ren, Zhen Huang, Ai-Xia Xu and Jun-Gang Dong
}

\begin{abstract}
Background: Acetolactate synthase (ALS)-inhibiting herbicides from the chemical families of sulfonylureas and imidazolinones are used worldwide. However, drift or sprayer contamination from some sulfonylurea herbicides causes a high level of male sterility in cruciferous species, especially oilseed rape (OSR). In this paper, we evaluated the gametocidal effects of 27 ALS-inhibiting herbicides that were sprayed on OSR plants at the bolting stage.

Results: OSR anther development was very sensitive to sublethal exposure to most ALS-inhibiting herbicides. The application of 18 out of the 20 tested sulfonylureas (except ethametsulfuron and ethoxysulfuron), two imidazolinones (imazethapyr and imazamox), and one sulfonylamino-carbonyltriazolinone (flucarbazone-sodium) at suitable rates could induce male sterility. Eight of the herbicides, including chlorsulfuron (at application rates of 60-120 mg/ha), halosulfuronmethyl (300-600 mg/ha), sulfosulfuron (400-600 mg/ha), triflusulfuron-methyl (500-750 mg/ha), pyrazosulfuron-ethyl (150-225 mg/ha), nicosulfuron (200-300 mg/ha), imazethapyr (750-1125 mg/ha), and imazamox (400-800 mg/ha), could induce over $90 \%$ male sterility and over $60 \%$ relative outcrossed seed set in six cultivars with different origins. These eight chemicals could be used as new gametocides for hybrid seed production. This study also examined the possibility of external application of these gametocides on several unstable Polima cytoplasmic male sterile and thermosensitive genic male sterile lines. Although the outcrossed seed set of the treated lines was slightly reduced, the gametocide application significantly increased the seed purity of the resulting hybrid.
\end{abstract}

Conclusion: The finding of the gametocidal effects of most sulfonylureas and imidazolinones are of great importance for developing new functions for ALS-inhibiting herbicides. The application of gametocides will also greatly promote the safe utilization of environment-sensitive male sterility in hybrid seed production. Unexpectedly, the application of three triazolopyrimidines (florasulam, flumetsulam, and penoxsulam) and one pyrimidinylthiobenzoate (bispyribac-sodium) did not cause male sterility, although these herbicides obviously inhibited the activity of ALS and plant growth. This result suggests that inhibition of ALS activity does not always lead to male sterility in plants, and these gametocides may also inhibit other biological functions vital for microspore development.

Keywords: Brassica napus, Male sterility, Gametocide, Chemical hybridizing agents, Herbicide, Sulfonylurea, Imidazolinone

\footnotetext{
* Correspondence: yu1009@nwafu.edu.cn

College of Agronomy, Northwest A\&F University, Yangling 712100, Shaanxi,
}

China

(c) The Author(s). 2020 Open Access This article is distributed under the terms of the Creative Commons Attribution 4.0 International License (http://creativecommons.org/licenses/by/4.0/), which permits unrestricted use, distribution, and reproduction in any medium, provided you give appropriate credit to the original author(s) and the source, provide a link to the Creative Commons license, and indicate if changes were made. The Creative Commons Public Domain Dedication waiver (http://creativecommons.org/publicdomain/zero/1.0/) applies to the data made available in this article, unless otherwise stated. 


\section{Background}

The large-scale adoption of hybrid oilseed rape (OSR, Brassica napus) contributes significantly to the oilseed supply worldwide. To economically produce hybrid seeds on a large scale, an effective male sterility (MS) system is crucial to reduce selfing and ensure outcrossing in the female parent because OSR is a predominantly self-pollinated crop [1]. At least seven MS systems are deployed for hybrid production in OSR, but all have some defects. First, many inheritable MS systems have been shown to be associated with some adverse effects on disease resistance, oil content, or other biological traits [2-8]. Second, it is timeconsuming and genotypically dependent to develop various male-sterile, maintainer, and restorer lines for cytoplasmic male sterile (CMS) and genic MS (GMS) systems. Third, there is great risk in applying Polima CMS [9] and thermosensitive male sterility (TMS) [10] in hybrid seed production in the world's second-highest OSR producer, China, because CMS and TMS are unstable when the temperature before flowering changes greatly $[8,10,11]$.

Chemical induction of male sterility (CIMS) by the use of gametocides/chemical hybridizing agents is an important method for hybrid seed production because the method avoids the problems of adverse effects from MS genes and saves the considerable time spent on prebreeding in the development of MS lines. The possible use of CIMS has been investigated in all major crops [12], but the use of many gametocides, for example, Genesis (clofencet) for wheat hybridization [13], has ceased owing to the high cost of gametocides, low seed production, or high risk of low seed purity (hybridity). However, rich experience in the utilization of CIMS has been accumulated for hybrid OSR, mainly in China. In recent decades, researchers have developed various types of gametocides for OSR, such as ethrel/ethephon [14], gibberellins, DPX-3773 [15], methyl arsenate [16], benzotriazole [17], and the synthetic detergent Surf Excel [18]. Unfortunately, to our knowledge, most of these gametocides are not practical for commercial use due to market availability, high pollution [16], or low efficacy. From this view, the development of effective and relatively cheap gametocides without environmental or health risks is very important for utilizing the heterosis of two-line hybrids in OSR.

It was found that the application of some sulfonylurea (SU) herbicides, such as tribenuron-methyl (TBM) [19] and amidosulfuron [20], had a strong gametocidal effect on OSR and allowed the treated plants to outcross. These SUs have been validated as useful gametocides for OSR and other Brassica species, and now, their different forms have been widely used by many institutes and seed companies in China [21]. More than 20 commercial hybrids based on SU gametocides have been released in China [21] by OSR breeders from Shaanxi, Hubei, Chongqing, Hunan, Sichuan, Jiangsu, Zhejiang, and Jiangxi provinces. SU herbicides target the acetolactate/acetohydroxylate synthase (ALS/ AHAS) enzyme, which is a key enzyme in the biosynthesis of valine, leucine, and isoleucine. There are hundreds of chemicals targeting ALS, including the five main families of SU, imidazolinone (IM), triazolopyrimidine (TP), pyrimidinylbenzoate $(\mathrm{PB})$, and sulfonylamino-carbonyltriazolinone (SC) [22]. Species from the Brassica family are very sensitive to most ALS-inhibiting herbicides, and either herbicide drift or sprayer contamination can cause phytotoxicity [23]. Thus, we pose a question: is it feasible to screen some new gametocides from these herbicides?

In the present paper, 27 ALS-inhibiting herbicides were sprayed on OSR at sublethal doses to compare the effects of the herbicides on the reproductive tissues. We also evaluated the seed quality and hybrid purity of some hybrid production trials using several selected herbicides. Another objective of the study was to achieve stable pollen sterility in several temperature-sensitive lines of CMS and TMS by gametocide application. The results are useful for evaluating the influences of herbicides on the reproduction of OSR and the development of new gametocides for OSR or other Brassica species.

\section{Results}

\section{The gametocidal effect of herbicides on Brassica napus}

Among the 27 different herbicides that were used in this experiment, 21 herbicides showed different gametocidal effects on the OSR cultivar Qin8C (Table 1). Application of 18 out of the 20 SUs (except ethametsulfuron and ethoxysulfuron) and two IMs, imazethapyr (Fig. 1a) and imazamox, at their suitable dose induced obvious MS in $B$. napus. The effect of the designed dose for the SC member flucarbazone-sodium was not ideal owing to the lower than $80 \%$ induction rate of MS plants (Table 1). Twelve of the SUs, namely, bensulfuron, chlorimuron-ethyl, chlorsulfuron (Fig. 1b), halosulfuron-methyl, flazasulfuron, metsulfuronmethyl, monosulfuron, nicosulfuron, oxasulfuron, pyrazosulfuron-ethyl, sulfosulfuron, and triflusulfuronmethyl (Fig. 1c), induced MS in more than $90 \%$ of the treated plants and lower damage in their suitable dose range. Too high of doses resulted in obvious pesticide damage, for example, growth stop and plant death (Fig. 1d).

The three TPs (florasulam, flumetsulam, and penoxsulam) and one PB (bispyribac-sodium) tested did not cause MS, although higher doses of these herbicides caused obvious plant injury, including severe leaf variegation (Fig. 1e-g) and temporal stop of stem node elongation, as did higher doses of ethoxysulfuron. We assayed the in vivo ALS activity and found that these herbicides also obviously inhibited the activity of the ALS enzyme, as did the SU herbicides, but the inhibition lasted only for times shorter than those from TBM and amidosulfuron (Fig. 2). 
Table 1 Gametocidal effect of sublethal dose application of various herbicides on OSR cv. Qin8C ${ }^{a}$

\begin{tabular}{|c|c|c|c|c|c|}
\hline Herbicide & Dosage (mg ha ${ }^{-1)}$ & Percentage of MS plant (\%) & SD & Percentage of damaged plant (\%) & SD \\
\hline \multirow[t]{4}{*}{ Bensulfuron } & 400 & 100.0 & 0.0 & 96.5 & 6.0 \\
\hline & 300 & 99.9 & 0.2 & 27.8 & 5.1 \\
\hline & 200 & 91.7 & 3.3 & 0.0 & 0.0 \\
\hline & 100 & 13.5 & 6.4 & 0.0 & 0.0 \\
\hline \multirow[t]{3}{*}{ Chlorimuron-ethyl } & 360 & 100.0 & 0.0 & 97.9 & 2.3 \\
\hline & 240 & 100.0 & 0.1 & 12.1 & 3.6 \\
\hline & 120 & 86.2 & 2.6 & 0.0 & 0.0 \\
\hline \multirow[t]{4}{*}{ Chlorsulfuron } & 240 & 100.0 & 0.0 & 95.3 & 5.3 \\
\hline & 180 & 100.0 & 0.0 & 49.3 & 6.9 \\
\hline & 120 & 100.0 & 0.0 & 11.1 & 1.4 \\
\hline & 60 & 90.4 & 4.3 & 1.6 & 1.6 \\
\hline \multirow[t]{3}{*}{ Ethoxysulfuron } & 405 & 0.0 & 0.0 & 96.9 & 5.4 \\
\hline & 270 & 0.0 & 0.0 & 26.4 & 6.1 \\
\hline & 135 & 0.0 & 0.0 & 0.0 & 0.0 \\
\hline \multirow[t]{3}{*}{ Ethametsulfuron } & 60,000 & 1.9 & 1.6 & 19.4 & 2.7 \\
\hline & 40,000 & 0.0 & 0.0 & 0.0 & 0.0 \\
\hline & 20,000 & 0.0 & 0.0 & 0.0 & 0.0 \\
\hline \multirow[t]{3}{*}{ Flazasulfuron } & 675 & 100.0 & 0.0 & 72.1 & 2.7 \\
\hline & 450 & 79.8 & 2.6 & 38.0 & 1.7 \\
\hline & 225 & 41.3 & 5.4 & 0.0 & 0.0 \\
\hline \multirow[t]{3}{*}{ Foramsulfuron } & 450 & 100.0 & 0.0 & 93.3 & 5.9 \\
\hline & 300 & 86.6 & 6.4 & 37.0 & 3.7 \\
\hline & 150 & 2.4 & 0.5 & 0.0 & 0.0 \\
\hline \multirow[t]{4}{*}{ Halosulfuron-methyl } & 1200 & 100.0 & 0.0 & 100.0 & 0.0 \\
\hline & 900 & 100.0 & 0.0 & 73.4 & 6.3 \\
\hline & 600 & 99.9 & 0.1 & 3.4 & 1.9 \\
\hline & 300 & 89.8 & 2.6 & 0.0 & 0.0 \\
\hline \multirow[t]{3}{*}{ Idosulfuron-methyl sodium } & 180 & 100.0 & 0.0 & 62.0 & 12.9 \\
\hline & 120 & 70.7 & 4.4 & 33.0 & 5.3 \\
\hline & 60 & 23.2 & 3.9 & 0.0 & 0.0 \\
\hline \multirow[t]{3}{*}{ Mesosulfuron-methyl } & 450 & 100.0 & 0.0 & 95.9 & 6.3 \\
\hline & 300 & 60.2 & 10.9 & 48.3 & 11.2 \\
\hline & 150 & 37.1 & 3.3 & 0.0 & 0.0 \\
\hline \multirow[t]{3}{*}{ Metsulfuron-methyl } & 360 & 100.0 & 0.0 & 95.6 & 7.6 \\
\hline & 240 & 99.9 & 0.2 & 17.2 & 3.0 \\
\hline & 120 & 56.2 & 9.8 & 13.3 & 6.7 \\
\hline \multirow[t]{4}{*}{ Monosulfuron } & 400 & 100.0 & 0.0 & 40.0 & 2.8 \\
\hline & 300 & 100.0 & 0.0 & 14.6 & 7.9 \\
\hline & 200 & 75.7 & 5.2 & 1.3 & 1.2 \\
\hline & 100 & 14.7 & 4.8 & 0.0 & 0.0 \\
\hline \multirow[t]{4}{*}{ Nicosulfuron } & 400 & 100.0 & 0.0 & 49.4 & 12.1 \\
\hline & 300 & 100.0 & 0.0 & 10.7 & 4.3 \\
\hline & 200 & 92.8 & 2.4 & 0.0 & 0.0 \\
\hline & 100 & 61.2 & 5.3 & 0.0 & 0.0 \\
\hline
\end{tabular}


Table 1 Gametocidal effect of sublethal dose application of various herbicides on OSR cv. Qin8C ${ }^{\mathrm{a}}$ (Continued)

\begin{tabular}{|c|c|c|c|c|c|}
\hline Herbicide & Dosage (mg ha ${ }^{-1)}$ & Percentage of MS plant (\%) & SD & Percentage of damaged plant (\%) & SD \\
\hline \multirow[t]{4}{*}{ Oxasulfuron } & 1200 & 100.0 & 0.0 & 98.1 & 3.3 \\
\hline & 900 & 100.0 & 0.0 & 34.9 & 9.5 \\
\hline & 600 & 99.8 & 0.2 & 4.4 & 1.9 \\
\hline & 300 & 62.8 & 4.9 & 0.0 & 0.0 \\
\hline \multirow[t]{4}{*}{ Pyrazosulfuron-ethyl } & 300 & 100.0 & 0.0 & 73.1 & 10.8 \\
\hline & 225 & 100.0 & 0.0 & 20.3 & 8.0 \\
\hline & 150 & 91.9 & 3.0 & 9.2 & 2.4 \\
\hline & 75 & 27.8 & 4.9 & 0.9 & 0.8 \\
\hline \multirow[t]{3}{*}{ Rimsulfuron } & 600 & 100.0 & 0.0 & 100.0 & 0.0 \\
\hline & 400 & 71.2 & 11.4 & 79.0 & 5.1 \\
\hline & 200 & 44.4 & 4.6 & 9.9 & 5.4 \\
\hline \multirow[t]{4}{*}{ Sulfometuron-methyl } & 2200 & 100.0 & 0.0 & 91.6 & 7.4 \\
\hline & 1650 & 100.0 & 0.0 & 45.1 & 4.5 \\
\hline & 1100 & 72.3 & 3.8 & 0.9 & 0.7 \\
\hline & 550 & 22.4 & 3.1 & 1.0 & 0.9 \\
\hline \multirow[t]{4}{*}{ Sulfosulfuron } & 800 & 100.0 & 0.0 & 89.4 & 7.5 \\
\hline & 600 & 100.0 & 0.0 & 18.7 & 7.2 \\
\hline & 400 & 99.9 & 0.1 & 7.8 & 5.0 \\
\hline & 200 & 82.1 & 2.4 & 0.9 & 0.0 \\
\hline \multirow[t]{3}{*}{ Thifensulfuron } & 300 & 100.0 & 0.0 & 93.4 & 2.9 \\
\hline & 200 & 77.3 & 5.1 & 36.6 & 2.9 \\
\hline & 100 & 30.4 & 8.7 & 0.0 & 0.0 \\
\hline \multirow[t]{4}{*}{ Triflusulfuron-methyl } & 1000 & 100.0 & 0.0 & 60.0 & 4.6 \\
\hline & 750 & 100.0 & 0.0 & 1.4 & 0.8 \\
\hline & 500 & 100.0 & 0.0 & 0.0 & 0.0 \\
\hline & 250 & 31.7 & 8.9 & 0.0 & 0.0 \\
\hline \multirow[t]{4}{*}{ Imazethapyr } & 1500 & 100.0 & 0.0 & 33.7 & 5.6 \\
\hline & 1125 & 100.0 & 0.0 & 17.8 & 4.2 \\
\hline & 750 & 94.6 & 4.9 & 0.6 & 1.1 \\
\hline & 375 & 33.6 & 9.7 & 0.0 & 0.0 \\
\hline \multirow[t]{4}{*}{ Imazamox } & 800 & 100.0 & 0.0 & 56.8 & 6.9 \\
\hline & 600 & 100.0 & 0.0 & 11.7 & 3.1 \\
\hline & 400 & 95.3 & 3.6 & 0.0 & 0.0 \\
\hline & 200 & 30.4 & 5.4 & 0.0 & 0.0 \\
\hline \multirow[t]{3}{*}{ Florasulam } & 600 & 0.0 & 0.0 & 96.7 & 2.9 \\
\hline & 400 & 0.0 & 0.0 & 33.8 & 7.8 \\
\hline & 200 & 0.0 & 0.0 & 0.0 & 0.0 \\
\hline \multirow[t]{3}{*}{ Flumetsulam } & 600 & 0.0 & 0.0 & 100.0 & 0.0 \\
\hline & 400 & 0.0 & 0.0 & 21.6 & 8.1 \\
\hline & 200 & 0.0 & 0.0 & 0.0 & 0.0 \\
\hline \multirow[t]{4}{*}{ Penoxsulam } & 600 & 0.0 & 0.0 & 100.0 & 0.0 \\
\hline & 450 & 0.0 & 0.0 & 20.3 & 5.4 \\
\hline & 300 & 0.0 & 0.0 & 2.7 & 2.2 \\
\hline & 150 & 0.0 & 0.0 & 0.0 & 0.0 \\
\hline
\end{tabular}


Table 1 Gametocidal effect of sublethal dose application of various herbicides on OSR cv. Qin8C ${ }^{\text {(Continued) }}$

\begin{tabular}{llllll}
\hline Herbicide & Dosage $\left(\mathrm{mg} \mathrm{ha}^{-1)}\right.$ & Percentage of MS plant (\%) & SD & Percentage of damaged plant (\%) & SD \\
\hline Bispyribac-sodium & 800 & 0.0 & 0.0 & 100.0 & 0.0 \\
& 600 & 0.0 & 0.0 & 78.7 & 5.7 \\
& 400 & 0.0 & 0.0 & 29.4 & 8.0 \\
Flucarbazone-sodium & 200 & 0.0 & 0.0 & 12.6 & 2.3 \\
& 300 & 90.2 & 5.4 & 70.4 & 15.9 \\
& 200 & 62.4 & 8.6 & 1.9 & 1.4 \\
\hline
\end{tabular}

Values in bold type show the treatment resulting in both satisfactory gametocidal effect and acceptable phytotoxicity. SD means standard deviation

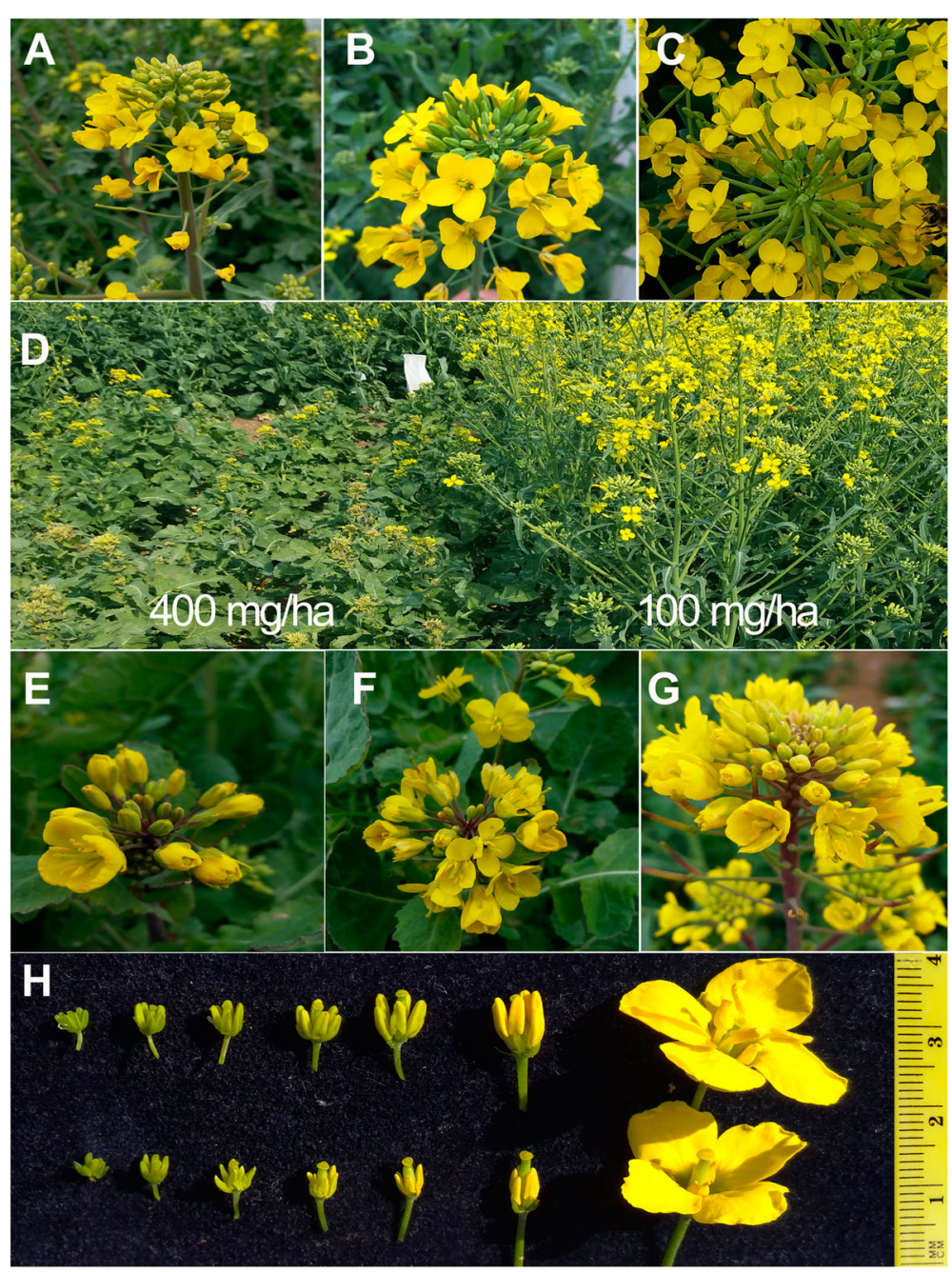

Fig. 1 Flowers of OSR plants exposed to sublethal doses of different herbicides. Completely sterile flowers caused by application of $750 \mathrm{mg} / \mathrm{ha}$ imazethapyr (a), $120 \mathrm{mg} / \mathrm{ha}$ chlorsulfuron (b), and $500 \mathrm{mg} / \mathrm{ha}$ triflusulfuron-methyl (c). Too high of doses of nicosulfuron (400 mg/ha) caused serious injury (left), but the $100 \mathrm{mg} / \mathrm{ha}$ treatment (right) resulted only in male sterility (d). The application of $6000 \mathrm{mg} / \mathrm{ha}$ bispyribac-sodium (e), $600 \mathrm{mg} / \mathrm{ha}$ flumetsulam (f), and $270 \mathrm{mg} / \mathrm{ha}$ ethoxysulfuron (g) did not cause male sterility in the anthers of the flower buds at different developmental stages. Comparison of the anther and filament size of the fertile (upper) and sterile (lower) flowers, where the male sterility was caused by chlorsulfuron (h) 


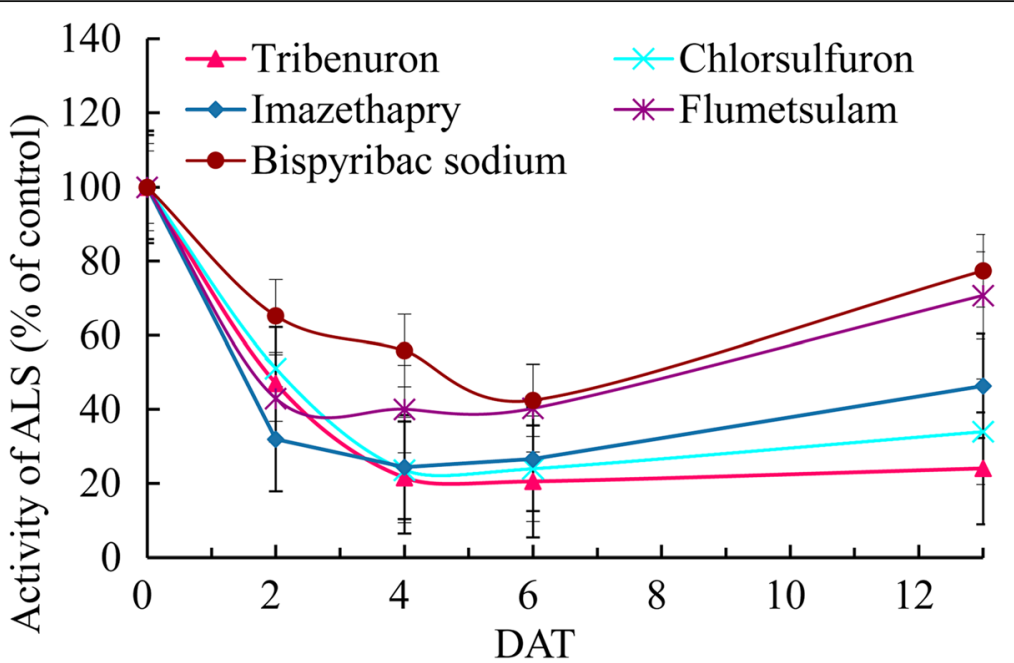

Fig. 2 Inhibition of the in vivo ALS activity of OSR flower buds by several herbicides. Treatments: tribenuron-methyl (60 mg/ha), chlorsulfuron (60 mg/ha), imazethapyr (750 mg/ha), bispyribac-sodium (6000 mg/ha), flumetsulam (600 mg/ha). DAT: days after treatment

\section{The phenotypic variations caused by ALS inhibitors}

The development of both the vegetative and reproductive parts of OSR was suppressed by most of the treatments, and the higher doses resulted in a more obvious suppression effect (Table 2). The male parts of the flower bud, the filaments and anthers, were more impacted by these gametocidal treatments (Table 2). At the early growth stage (bud length $\leq 3 \mathrm{~mm}$ ), no obvious difference was found visually in the flower buds of the plants treated with $100 \mathrm{mg} /$ ha chlorsulfuron. After the uninucleate stage (flower bud length $3-3.5 \mathrm{~mm}$ ), the elongation of the filaments and the expansion of the anthers were inhibited, and ultimately, all the anthers withered before blooming (Fig. 1h). In contrast, the female part, the pistil, was not severely affected (Fig. 1h). These results showed that the stamen development of OSR is more sensitive to ALSinhibiting gametocides than that of the pistil.

In addition to MS, all treatments at higher doses caused stunting of growth, chlorosis in leaves, and fading in flower buds in the first few days after treatment. The degree of plant injury depended on the application rate of herbicides, and injury was more evident for the treatments with higher doses. For example, the slight chlorosis in the leaves caused by an application dose of $120 \mathrm{mg} / \mathrm{ha}$ of chlorsulfuron recovered in three to 5 days, but the recovery after an application dose of $240 \mathrm{mg} /$ ha required more than 1 week. The height of the plants treated with chlorsulfuron at an application dose of $240 \mathrm{mg} /$ ha decreased, the beginning of flowering was delayed by two to 5 days, and the duration of flowering on the main inflorescence was shortened. The length of the pistil, petal size, and flowering duration were also reduced by higher doses (Table 2).

\section{Validation of the gametocidal activity of eight selected herbicides}

All eight selected herbicides (chlorsulfuron, halosulfuron-methyl, nicosulfuron, pyrazosulfuron-ethyl, sulfosulfuron, triflusulfuron-methyl, imazethapyr, and imazamox) showed strong gametocidal effects, comparable to the standard gametocide TBM (Table 3). Exposure to these herbicides resulted in almost $0 \%$ selfed seed set and over $60 \%$ relative outcrossed seed set in comparison to the control. The lower application doses led to moderate phytotoxicity (Table 3 ). The higher application doses resulted in higher MS, but the consequent

Table 2 Effect of chlorsulfuron treatments on several biological traits of OSR cV. Qin8C ${ }^{a}$

\begin{tabular}{llllllll}
\hline $\begin{array}{l}\text { Dose } \\
(\mathrm{mg} / \mathrm{ha})\end{array}$ & $\begin{array}{l}\text { Petal width } \\
(\mathrm{mm})\end{array}$ & $\begin{array}{l}\text { Petal length } \\
(\mathrm{mm})\end{array}$ & $\begin{array}{l}\text { Pistil length } \\
(\mathrm{mm})\end{array}$ & $\begin{array}{l}\text { Delay days of } \\
\text { first flower open }\end{array}$ & $\begin{array}{l}\text { Duration of male } \\
\text { sterility (day) }\end{array}$ & $\begin{array}{l}\text { Duration of flowering } \\
\text { on terminal raceme }(\text { day })\end{array}$ & \begin{tabular}{l} 
Plant height $(\mathrm{cm})$ \\
\hline 240
\end{tabular} \\
\hline $1.87 \mathrm{~B}$ & $9.33 \mathrm{C}$ & $10.81 \mathrm{~B}$ & $3.05 \mathrm{~A}$ & $16.05 \mathrm{~B}$ & $11.40 \mathrm{~B}$ & $109.91 \mathrm{~B}$ \\
180 & $8.99 \mathrm{~A}$ & $10.10 \mathrm{~B}$ & $11.36 \mathrm{AB}$ & $2.05 \mathrm{~B}$ & $21.10 \mathrm{~A}$ & $19.05 \mathrm{~A}$ & $154.20 \mathrm{~A}$ \\
120 & $9.04 \mathrm{~A}$ & $10.50 \mathrm{~B}$ & $11.54 \mathrm{AB}$ & $0.70 \mathrm{C}$ & $17.20 \mathrm{~B}$ & $20.20 \mathrm{~A}$ & $165.82 \mathrm{~A}$ \\
0 & $9.21 \mathrm{~A}$ & $11.41 \mathrm{~A}$ & $11.79 \mathrm{~A}$ & $0.35 \mathrm{C}$ & $0.00 \mathrm{C}$ & $20.00 \mathrm{~A}$ & $164.96 \mathrm{~A}$ \\
\hline
\end{tabular}

atetters after data indicate significant differences at 0.01 level 
Table 3 Average effects of nine gametocides on the fertility of six Brassica napus cultivars

\begin{tabular}{|c|c|c|c|c|c|c|c|}
\hline Chemical & Dose mg/ha & $\begin{array}{l}\text { Percentage of male } \\
\text { sterile plant }\end{array}$ & SD & $\begin{array}{l}\text { Self-pollinated } \\
\text { seed-setting rate }\end{array}$ & SD & $\begin{array}{l}\text { Seed-setting rate under } \\
\text { open pollination }\end{array}$ & SD \\
\hline Chlorsulfuron & 60 & 97.15 & 3.62 & 0.05 & 0.19 & 83.65 & 7.77 \\
\hline Chlorsulfuron & 120 & 100.00 & 0.00 & 0.00 & 0.00 & 61.31 & 8.38 \\
\hline Halosulfuron methyl & 300 & 98.09 & 2.69 & 1.17 & 1.07 & 72.70 & 10.97 \\
\hline Halosulfuron methyl & 600 & 100.00 & 0.00 & 0.00 & 0.00 & 46.15 & 8.98 \\
\hline Sulfosulfuron & 400 & 99.40 & 1.44 & 0.00 & 0.00 & 86.87 & 6.47 \\
\hline Sulfosulfuron & 600 & 100.00 & 0.00 & 0.00 & 0.00 & 59.92 & 11.09 \\
\hline Triflulsulfuron-methyl & 500 & 96.97 & 3.09 & 0.88 & 0.65 & 90.11 & 7.84 \\
\hline Triflulsulfuron-methyl & 750 & 100.00 & 0.00 & 0.00 & 0.02 & 76.81 & 8.27 \\
\hline Nicosulfuron & 200 & 98.95 & 2.07 & 0.00 & 0.01 & 78.22 & 8.12 \\
\hline Nicosulfuron & 300 & 100.00 & 0.00 & 0.00 & 0.00 & 68.70 & 9.02 \\
\hline Pyrazosulfuron-ethyl & 150 & 89.73 & 4.89 & 5.36 & 4.42 & 87.06 & 20.58 \\
\hline Pyrazosulfuron-ethyl & 225 & 99.90 & 0.43 & 0.00 & 0.00 & 62.00 & 7.76 \\
\hline Imazethapyr & 750 & 90.60 & 3.05 & 2.15 & 1.27 & 98.21 & 9.48 \\
\hline Imazethapyr & 1125 & 99.79 & 0.62 & 0.00 & 0.00 & 74.52 & 8.72 \\
\hline Imazamox & 400 & 93.13 & 5.08 & 1.53 & 1.61 & 105.20 & 10.00 \\
\hline Imazamox & 600 & 98.98 & 1.98 & 0.00 & 0.02 & 86.46 & 6.39 \\
\hline TBM & 60 & 99.71 & 0.84 & 0.01 & 0.02 & 84.02 & 7.57 \\
\hline TBM & 120 & 100.00 & 0.00 & 0.00 & 0.00 & 65.52 & 8.09 \\
\hline Control & 0.0 & 0.00 & 0.00 & 100.00 & 0.00 & 100.00 & 0.00 \\
\hline
\end{tabular}

problem of pesticide damage resulted in shortened inflorescence and poor seed set (Table 3). For example, seed yields under open pollination from the application of 60 and $120 \mathrm{mg} / \mathrm{ha}$ chlorsulfuron were 83.65 and $61.31 \%$ that of the control, respectively. The reduction in outcrossed seed yield observed in most treatments was due to the reductions in both the number and length of siliques.

\section{The response of different OSR genotypes to gametocides} The results for analysis of variance of the field experiment in the split-plot design (Additional file 1: Table S2) showed that the gametocidal effects (percentage of MS plant) and phytotoxicity (open-pollination seed-set rate) on the six cultivars (main plots in the field experiment), treatment effects of the two doses (subplots) of the nine gametocides, and the interaction between the genotypes and gametocide treatments were significant. The differences among the selfed seed-set rates of different gametocide treatments were also significant. We found that the gametocidal effect had a genotype preference, and the cultivars with vigor seedlings (H15 and M267) needed a higher dose than cultivars with weak seedlings (Zhong9 and Zhe18). There was an obvious association between treatment with the optimal dose and reduced plant biomass in four batch seedlings of cultivar M267, whose seeds were sown in batches at five-day intervals (Fig. 3).

\section{Seed set of small-scale trials for hybrid production}

A total of $6.05 \mathrm{~kg}$ and $8.38 \mathrm{~kg}$ of hybrid seeds were collected from the two isolated cages for the biparental crosses of Zhong9 CIMS $\times$ BC530 and Q5005 CIMS $\times$ BC530, which were $18.78 \%$ lower and $0.85 \%$ higher than their corresponding Polima CMS lines, respectively. The thousand-grain weight and germination rate of the seeds were slightly and not significantly lower, respectively, than those of the hybrid seeds from their corresponding CMS lines due to many unfilled seeds (Table 4). The decreases in seed yield, seed weight and germination rate intimated either impairment of the seed development or a decrease in the silique number of the CIMS plants. The true hybrid seedlings resembled the male parent BC530 in the trait of deep-divided leaves and thus could be easily distinguished from the undesirable plants derived from female parent selfing. The average hybridity (hybrid seed percentage) of the seeds collected from Zhong9 CIMS $\times$ BC530 and Q5005 CIMS $\times$ BC530 were 93.0 and $91.4 \%$ (Table 4), respectively, which was higher than the national standard of $85 \%$ for the hybridity of OSR hybrid seed lots.

\section{The effect of gametocide on eliminating pollen in CMS and TMS lines}

In the first week of flowering in this experimental season, the pollen viability of the CMS lines Zheyou50-A, Q5005-A, SP2-A, and TMS SP2S was very high (Table 5). 


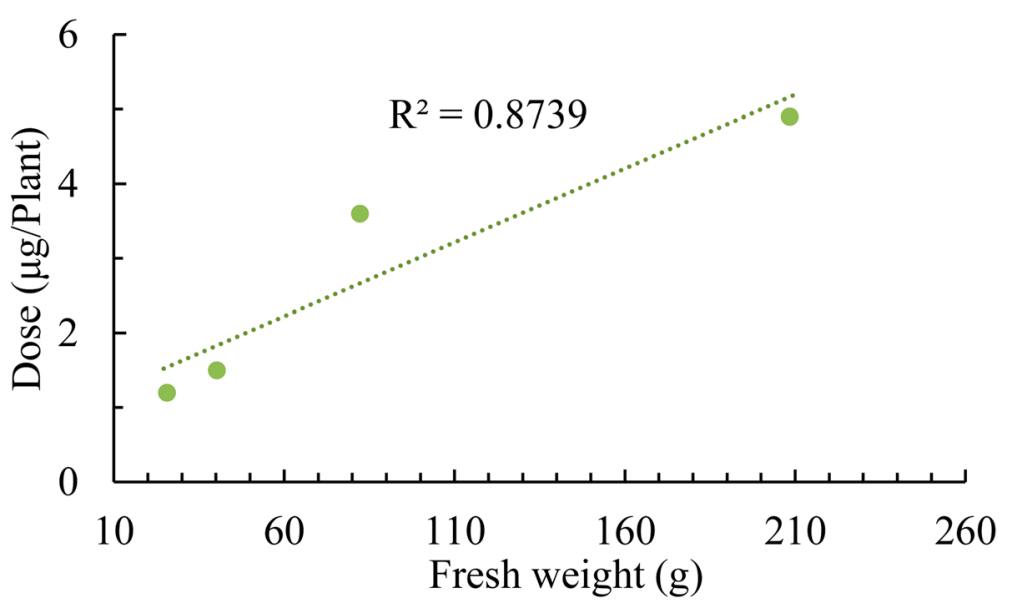

Fig. 3 Relationships between the optimal dose of chlorsulfuron with the fresh weight (g) of cultivar M267

This defect prevents their safe utilization in hybrid production. Exposure of these lines to chlorsulfuron at a 100 $\mathrm{mg} /$ ha rate resulted in nearly $100 \% \mathrm{MS}$ in the population and over the whole flowering period (Table 5). The stamens of CMS SP2-A + CIMS and TMS SP2S + CIMS were much smaller than those of the fertile line SP2, partially sterile CMS SP2-A, and fertile phase of SP2S TMS at low temperature (Fig. 4a). Compared to the flowers of the fertile maintainer line SP2 (Fig. 4b), CMS SP2-A was partially sterile (Fig. 4c), and CMS SP2-A treated by chlorsulfuron (CMS + CIMS) was completely sterile (Fig. 4d). The differences were notable when the pollen viability was examined under a microscope. The fertile anthers contained plentiful round pollen grains (Fig. 4e). Polima CMS line SP2-A presented partial MS because one or two of the four locules in the anther swelled and produced some pollen grains, leading to a crescent anther (Fig. 4f). However, the aborted anthers from CMS + CIMS were undeveloped, containing no pollen (Fig. 4g) or only a few distorted pollen shells.

Pistil function was also somewhat affected by gametocide application. The outcrossed seed set of chlorsulfurontreated plants of CMS lines, including Zhong9-A, SapphireA, Zheyou50-A, SP2-A, and TMS line SP2S, decreased by $26.5,12.7,3.4,10.8$, and $7.3 \%$ compared with their untreated controls, respectively, with an exceptional increase of 2.8\% in Q5005-A. Although the seed set was depressed, the self-pollination was constrained well, as evidenced by almost no selfed seed set under bagged conditions and a high level of seed hybridity under outcrossed conditions (Table 5). Other gametocide treatments, such as triflusulfuron-methyl, nicosulfuron, and imazethapyr, could also induce a significantly high percentage of MS in the treated plants of CMS and TMS lines (unpublished data).

\section{Discussion}

SUs and IMs will be substantial chemical sources for the selection of new gametocides

Most SU herbicides can strongly inhibit the growth of weeds and volunteer crops, and some of them also have good gametocidal effects on OSR and other sensitive plants [20]. This effect cannot be ignored in the evaluation of herbicide damage and the safe use of ALSinhibiting herbicides. A gametocide is rather difficult to invent because it must have strong positional selectivity between the stamen and pistil. The well-known herbicide glyphosate caused transient MS in Brassica [24], but we found that it caused severe damage to the pistil and leaf (unpublished). Our results suggested that it is practical to screen gametocides from ALS-inhibiting herbicides, especially SUs and IMs, because exposure of different OSR cultivars to the eight selected gametocides resulted in a high degree of MS as well as lower phytotoxicity on the pistil. At present, more than $50 \mathrm{SU}$ and

Table 4 The quality of seeds obtained from the plants exposed to chlorsulfuron

\begin{tabular}{lllll}
\hline Seed samples & Seed yield (g/plant) & 1000-grain-weight $(\mathrm{g})^{\mathrm{a}}$ & ${\text { Germination rate }(\%)^{\mathrm{a}}}$ & ${\text { Hybridity }(\%)^{\mathrm{b}}}^{\mathrm{a}}$ \\
\hline Zhong9 CIMS× BC530 & $13.75 \pm 0.66^{* *}$ & $3.52 \pm 0.08$ & $90.7 \pm 3.10$ & $93.0 \pm 1.87$ \\
Zhong9-A× BC530 & $16.93 \pm 0.95$ & $3.74 \pm 0.08$ & $97.2 \pm 2.23$ & $96.7 \pm 2.27$ \\
Q5005 CIMS× BC530 & $19.05 \pm 0.94$ & $3.86 \pm 0.08$ & $92.5 \pm 2.10$ & $91.4 \pm 2.80$ \\
Q5005-A× BC530 & $18.89 \pm 0.83$ & $3.98 \pm 0.07$ & $96.8 \pm 2.00$ & $92.8 \pm 2.53$ \\
\hline
\end{tabular}

${ }^{a}$ The coarse seed lot contained unfilled seeds

${ }^{\mathrm{b}}$ The seed lot experienced cleaning process and contained only plump seeds

The symbol ** indicates significant difference at 0.01 level 
Table 5 Effect of application of $100 \mathrm{mg} /$ ha chlorsulfuron on environment sensitive male-sterile lines

\begin{tabular}{|c|c|c|c|c|c|c|c|}
\hline Male sterile line & Gametocide treatment & $\begin{array}{l}\text { Pollen viability at } \\
\text { early flowering stage \% }\end{array}$ & SD & $\begin{array}{l}\text { Seed-set of out-crossing } \\
(\mathrm{g} / \text { plant })^{c}\end{array}$ & SD & Hybridity of samples $\%^{c}$ & SD \\
\hline \multirow[t]{2}{*}{ Zhong9-A } & untreated & 5.46 & 4.38 & 17.79 & 1.10 & 97.50 & 1.55 \\
\hline & treated & $0.01^{b}$ & 0.04 & $13.08^{b}$ & 1.06 & 100.00 & 0.00 \\
\hline \multirow[t]{2}{*}{ Q5005-A } & untreated & 10.08 & 4.31 & 20.19 & 1.08 & 92.50 & 5.06 \\
\hline & treated & $0.05^{b}$ & 0.07 & 20.75 & 1.86 & 98.69 & 1.88 \\
\hline \multirow[t]{2}{*}{ Sapphire-A } & untreated & 2.07 & 2.07 & 19.37 & 1.28 & 96.40 & 1.82 \\
\hline & treated & 0.00 & 0.00 & $16.91^{\mathrm{b}}$ & 1.20 & 100.00 & 0.00 \\
\hline \multirow[t]{2}{*}{ Zheyou50-A } & untreated & 17.20 & 6.28 & 21.46 & 1.12 & 90.13 & 3.40 \\
\hline & treated & $0.00^{\mathrm{b}}$ & 0.00 & 20.73 & 0.74 & $99.73^{\mathrm{a}}$ & 0.47 \\
\hline \multirow[t]{2}{*}{ SP2-A } & untreated & 30.21 & 14.47 & 22.82 & 1.51 & 85.85 & 3.99 \\
\hline & treated & $0.00^{b}$ & 0.01 & $20.35^{b}$ & 1.24 & $98.52^{b}$ & 1.22 \\
\hline \multirow[t]{2}{*}{ SP2S } & untreated & 59.51 & 10.45 & 20.53 & 1.72 & 96.88 & 2.39 \\
\hline & treated & $0.01^{b}$ & 0.03 & 19.03 & 1.53 & 100.00 & 0.00 \\
\hline
\end{tabular}

The symbol ${ }^{\mathrm{a}}$ and ${ }^{\mathrm{b}}$ indicate significant difference at 0.05 and 0.01 level respectively. ${ }^{\mathrm{c}}$ The plants were pollinated by the paternal line $\mathrm{BC} 530$

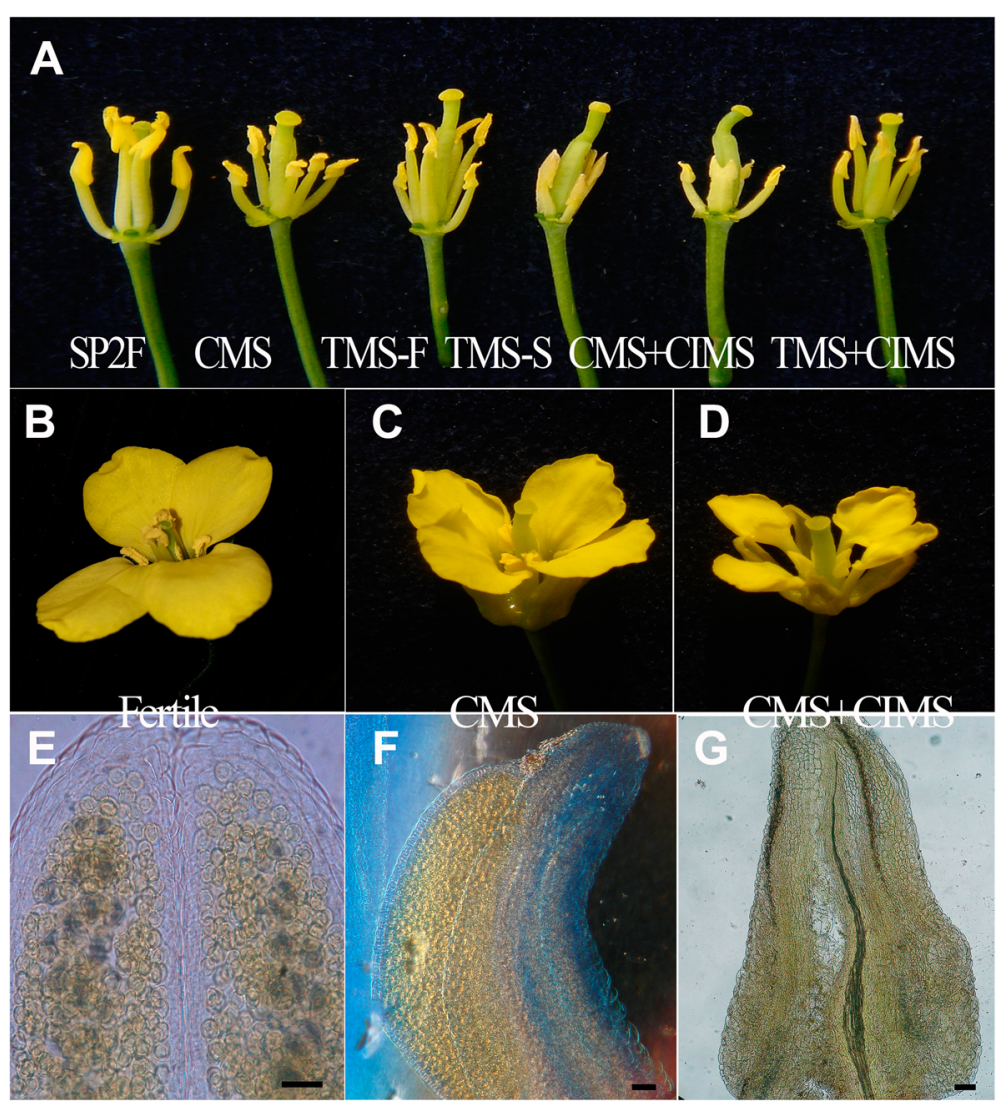

Fig. 4 Phenotypic comparison of different flowers. a The stamens of maintainer line SP2, CMS SP2-A, TMS SP2S-under low temperature, TMS SP2S-under high temperature, CMS SP2-A + CIMS, and TMS SP2S + CIMS. The flowers of maintainer line SP2 (b, fertile), CMS SP2-A (c, partially sterile), and CMS SP2-A + CIMS (d, sterile). Pollen grains in the anthers of maintainer line SP2 (e, fertile), CMS SP2-A (f, partially sterile), and CMS SP2-A + CIMS (g, sterile). Scale bar $=50 \mu \mathrm{m}$ 
IM herbicides have been commercialized, and small changes in the substituents may result in significant changes in their biological activity and species selectivity. There are thousands of compounds with the basic structures of SU, IM, TP, etc., and these substances provide a large bank for screening new gametocides. Limited by the experimental scale, we did not validate the gametocidal effects of the rest of the herbicides, including bensulfuron, chlorimuron-ethyl, metsulfuron-methyl, monosulfuron, and oxasulfuron. We believe that some of these herbicides may also be useful gametocides if more doses are tested for gametocidal treatment.

\section{Gametocidal effects are affected by various factors}

We found that the TPs (florasulam, flumetsulam, and penoxsulam) and PB (bispyribac-sodium) tested did not cause MS, although these herbicides obviously inhibited the activity of the ALS enzyme. This result suggests that inhibition of ALS activity is not a guarantee of MS, as previous studies have suggested [25], and SU gametocides may also affect some other biological functions necessary for microspore development, such as plastid structure, tissue autophagy, ethylene release, detoxification, fatty acid metabolism, and cell cycles [26, 27]. These pathways would also be interesting for study with respect to the modes of action of SU and IM gametocides.

The existence of a genotypic effect from the gametocides in this study suggests that minor adjustment of the application dose is needed when different OSR cultivars are used as female parents for hybrid production. Several $A L S$ gene mutations were found to be strongly tolerant of SUs [28-30], and these mutations in the male parent can be used in hybrid seed production based on CIMS [28]. In most cases, genotypic susceptibility is not a consequence of $A L S$ gene mutation but from stems from some physiological aspects, such as absorption, transport, biological detoxification and defense responses [26, 27]. In our experience, some OSR cultivars with traits such as high growth speed, large biomass, thick wax powder, and long duration of flowering will need a higher application dose of SU gametocide. In addition to plant genotypic differences, other factors, including plant uniformity, plant developmental stage, climate conditions, adjuvants, and sprayer equipment, also influence the gametocidal effect.

\section{Application of gametocide to enhance the effectiveness of OSR breeding}

The application of SU and IM gametocides can greatly enhance the effectiveness of OSR breeding by simplifying hybrid breeding programs, among other uses. Researchers attempt to use chemicals to kill pollen in environment-sensitive MS lines of OSR and other crops, such as rice TMS [31], to prevent the risk of fertility fluctuations in hybrid production systems. Our results showed that it is possible to achieve 100\% MS in CMS or TMS lines with external application of some SU gametocides. Thus, the application of the double MS systems called 'CMS + CIMS' and 'TMS + CIMS' will greatly diminish the risk of seed production based on environment-sensitive MS. Moreover, because SU and IM gametocides can elicit nonheritable MS in plants, this technique will not only allow the production of hybrid seeds from large numbers of intervarietal and even interspecific crosses but also allow the production of many types of varieties in addition to single cross hybrids, such as reciprocal cross, triple-cross and doublecross hybrids and composite varieties, which are not allowed by using a heritable MS system due to fertility segregation. Thus, CIMS will greatly expand the utilizable range of OSR heterosis. These gametocides can also be used in a recurrent selection breeding program, with many advantages over using a GMS [32] because temporal CIMS can be achieved on any individual plant and at any cycle of selection without ever considering fertility segregation such as in a GMS [32]. In addition, an efficient SU or IM gametocide can be used by OSR breeders to replace the troublesome manual emasculation in sexual hybridizing.

\section{Conclusions}

The application of most SUs and IMs had strong gametocidal effects as well as acceptable phytotoxic effects on OSR. This finding is of great importance for developing new functions for ALS-inhibiting herbicides. None of the tested TPs and PB resulted in MS, although these herbicides also obviously inhibited the activity of the ALS enzyme. This evidence suggests that inhibition of ALS activity may not always lead to plant MS, as previous studies have suggested, and ALS-inhibiting gametocide may also affect some other biological functions necessary for microspore development.

\section{Methods \\ Plant materials}

Seven OSR cultivars with different pedigrees and origins (Table 6), namely, Qin8C, Zhong9, Q5005, Zhe18, H15, Zheyou50, and M267, were used to evaluate the gametocidal effects. In addition, five Polima CMS lines, Zhong9-A, Sapphire-A, Q5005-A, Zheyou50-A, SP2-A, and the TMS line SP2S (Table 6), were used to study fertility regulation by gametocide. An inbred line, BC530, with a dominant trait of deeply divided leaves served as the male parent for cross-pollination because the presence of this trait in the derived $F_{1}$ plants can indicate successful gene transfer from the male parent. The seed samples of these plant accessions (Table 6) are maintained by Dr. C.Y. Yu at Northwest A\&F University. 
Table 6 Pedigrees and origins of the plant accessions used in this study

\begin{tabular}{llll}
\hline Accession & Type & Pedigree & Origin $^{\text {a }}$ \\
\hline Qin8C & Breeding line & Variety Qinyou8 & AAS of Xianyang, China \\
Zhong9 & Breeding line & Variety Zhongshuang9 & ORI, CAAS, Hubei, China \\
Q5005 & Breeding line & Variety Qianyou28 & AAS of Guizhou, China \\
Zhe18 & Breeding line & Variety Zheyou18 & AAS of Zhejiang, China \\
H15 & Breeding line & Variety Huyou15 & AAS of Shanghai, China \\
Zheyou50 & Breeding line & Variety Zheyou50 & AAS of Zhejiang, China \\
M267 & Breeding line & Variety Zheyou267 & AAS of Zhejiang, China \\
Sapphire & Breeding line & Variety AV Sapphire & Australia \\
BC530 & Breeding line & Variety Shaanyou16 & NWAFU, China \\
SP2S & TGMS line & Reference [10] & NWAFU, China \\
SP2 & Fertile near-isogenic line of SP2S & Reference [10] & NWAFU, China \\
Zhong9-A & Male sterile line & CMS maintained by Zhong9 & NWAFU, China \\
Q5005-A & Male sterile line & CMS maintained by Q5005 & NWAFU, China \\
Sapphire-A & Male sterile line & CMS maintained by Sapphire & NWAFU, China \\
Zheyou50-A & Male sterile line & CMS maintained by Zheyou50 & NWAFU, China \\
SP2-A & Male sterile line & CMS maintained by SP2 & NWAFU, China \\
\hline
\end{tabular}

${ }^{a}$ AAS Academy of Agricultural Science, CAAS China Academy of Agricultural Science, NWAFU Northwest A\&F University, ORI Oilcrop Research Institute

\section{Screening of potential gametocide for OSR}

The experiment was conducted mainly in the breeding nursery of Northwest A\&F University, Yangling (longitude 108.07, latitude 34.28), China. The altitude of the experimental fields is $450 \mathrm{~m}$, which is located in the temperature area. The long-term annual sum of rainfall is $600-800 \mathrm{~mm}$, and the average daily temperature is $12.9^{\circ} \mathrm{C}$. The plants were grown in the experimental field in autumn, and gametocide treatment was carried out in the next spring. The field management during the experiment followed local practices, and weed control was performed manually. This experiment in the plant breeding nursery complied with the Regulations on Pesticide Administration in China.

The layout of the preliminary screening of new gametocides was a completely randomized design with three replications. In each plot, there were at least 45 seedlings of cultivar Qin8C. Each plot had three rows, and each row was two meters long with a row spacing of $40 \mathrm{~cm}$. Twenty-seven herbicides (Table 1) were used in the study, including 20 SUs, two IMs (imazethapyr and imazamox), three TPs (flumetsulam, florasulam and penoxsulam), one PB (bispyribac-sodium), and one SC (flucarbazone-sodium). The trade names and chemical structures of all herbicides can be found in Additional file 1: Table S1. Based on the data from TBM and amidosulfuron, the empirical range of sublethal doses for each ALS-inhibiting herbicide was designed as 1,2, 3, and $4 \%$ dilutions (higher doses were also used for the TP and PB members) of the recommended rate for weed control. All the doses/application rates in this paper refer to the active ingredient. An adjuvant saturate (Haina Co. Ltd., Qingdao, China) was added at approximately $0.1 \%$ concentration to enhance the adhesion of aqueous droplets on the leaf surface. Application was carried out using high pressure pump sprayers at the bolting stage of the plants, with the length of largest flower buds being $\leq 3 \mathrm{~mm}$ length (i.e., when the largest microspore is at the uninucleate stage). The solution volume was calibrated to approximately $2 \mathrm{ml}$ per plant. The control plants were sprayed with water.

After herbicide treatment, the growth speed (stem elongation), flowering time, and flower size of the plants were investigated. Phytotoxicity was defined in this study as growth stop, upper leaf shedding, and flower bud wilt. The number of MS and fertile (including semisterile) plants were occasionally counted. The flower buds collected from ten random plants were fixed in a solution (ethanol/acetic acid 3:1 V/V) overnight and stored in 70\% alcohol at $4{ }^{\circ} \mathrm{C}$. The anthers of the flower buds were stained with acetocarmine solution and observed under a light microscope to estimate the pollen viability [19]. A viable pollen grain is oval shaped, and its cellular content is stained by acetocarmine, while a dead grain only has an empty shell that cannot be stained. The flower buds were processed with clearing agent methyl salicylate [20] to observe the pollen distribution in the anthers. The in vivo ALS activities of the flower buds treated with several classic herbicides were assayed as previously described [26].

\section{Validation of gametocidal effects of eight selected gametocides}

An experiment was conducted to test the reaction of the six cultivars of semiwinter OSR, including Zhong9, Q5005, 
Zhe18, H15, Zheyou50, and M267, to two doses (modified from the suitable range in the above experiment) of eight selected gametocides in comparison with both the standard gametocide TBM and untreated control. The experimental plots were arranged in a split-plot design with three independent replicates. The six cultivars were placed in the main plot, and the gametocide treatments were in subplots. Each subplot contained four rows with 60 seedlings. The flowering time and the percentage of completely sterile plants in each plot were recorded. Ten plants were selected randomly and bagged to test the seed set under selfpollination. The seed-set rate from another ten plants under open/cross pollination was used to estimate the phytotoxic effect. The seed-set rates under self-pollination conditions and cross-pollination conditions were calculated with the following formula: percent seed-set rate $=$ (number of seeds per treated plant / number of seeds per control plant) $\times 100$.

To compare the optimal doses for seedlings with different plant heights or biomasses, we sowed the seeds of cultivar M267 in the field four times at five-day intervals and obtained four batches of seedlings with gradually reduced biomass due to the temperature decrease in the autumn. Every ten plants in these four batches of seedlings were sprayed with a series of solutions with a concentration gradient of $30,40 \quad \ldots \quad \ldots \quad 90,100 \mathrm{mg} / \mathrm{L}$ chlorsulfuron, at a carrier volume of $5 \mathrm{ml} /$ plant. The optimal dose, i.e., the dose resulting in nearly 100\% MS and the lowest phytotoxicity, in each batch of seedlings was determined. Linear regression analysis was performed to evaluate the relationship between the optimal doses and plant biomass.

\section{Small-scale hybrid seed production and test of seed quality}

A seed production trial was carried out in isolated cages to produce the necessary amount of experimental hybrid seed for yield trials. The maternal parents, Zhong9 and Q5005, were grown in two isolated plots that were covered by nylon mesh, along with the paternal BC530 with deep-divided leaves. Each isolated plot had a size of 6 by $8 \mathrm{~m}$ and contained 450 female seedlings. The plants were grown at the same density as that of the previous experiments, with a 2: 1 row ratio for each female to male parent. The female parents were exposed to $100 \mathrm{mg} / \mathrm{ha}$ chlorsulfuron when the main inflorescence of the bolting plants emerged from the upper leaf. Thirteen days later, the chlorsulfuron was applied again at a double dose. Cross-pollination was performed by manually shaking the male parent and dispersing its pollen grains to the style of the female parents. At maturity, seeds were collected from the treated female plants, and the seed germination rate was investigated in petri dishes containing moistened filter paper. The thousand-grain-weight of the hybrid seeds was determined, and then the seed samples were sown in the field. Two months later, the hybridity (percentage of true hybrid seeds) was estimated from the percentage of plants with the indicating trait of deeply divided leaves.

\section{Effect of chlorsulfuron exposure on unstable inherited MS lines \\ From OSR microspore development to the flowering} period (early March to mid-April), the daytime temperature in Yangling continually increased from approximately $5{ }^{\circ} \mathrm{C}$ to $25^{\circ} \mathrm{C}$. Each set of four rows of the plants of the TMS SP2S and Polima CMS lines Zhong9A, Q5005-A, Sapphire-A, Zheyou50-A, and SP2-A were treated with $100 \mathrm{mg} / \mathrm{ha}$ chlorsulfuron solution before the buds reached $3.5 \mathrm{~mm}$ long. Another set of plants treated with water served as the control. Ten randomly selected plants were bagged to test the selfed seed-set rate, and the rest were left to be cross-pollinated by the male parent BC530. The seed set of 10 sampled plants (under self-pollinated conditions as well as open-pollinated conditions) was investigated.

\section{Statistical analysis}

The gametocidal effect and phytotoxicity of the chemicals were analyzed for variance using the statistical analysis package DPS 7.5 [33]. The means were tested by the least significant difference method at the $p<0.01$ and $p<0.01$ levels. To compare the effects of eight candidates to that of TBM, the effects of cultivars (main plots) and application doses (subplots) and the interactions between them were analyzed by using a split-plot model in DPS software. The results are shown in Additional file 1: Table S2.

\section{Supplementary information}

Supplementary information accompanies this paper at https://doi.org/10. 1186/s12870-020-2278-9.

Additional file 1: Table S1. The related information of herbicides used in the study. Table S2. ANOVA table for two-factor split plot designs.

\section{Abbreviations \\ ALS: Acetolactate synthase; CIMS: Chemical induction of male sterility; CMS: Cytoplasmic male sterility; IM: Imidazolinone; MS: Male sterility; OSR: Oilseed rape; PB: Pyrimidinylbenzoate; SC: Sulfonylamino- carbonyltriazolinone; SU: Sulfonylurea; TBM: Tribenuron-methyl; TMS: Thermosensitive male sterility; TP: Triazolopyrimidine}

\section{Acknowledgements}

The authors would like to thank the National Pesticide Engineering Research Center of Nankai University and Jiangsu Institute of Ecomones Co., Ltd. for providing some of the herbicide samples.

\section{Authors' contributions}

CYY conceived and designed the experiments and prepared the manuscript; $J L L, Q G$, and LSR carried out the experiments; ZH, AXX and JGD analyzed the data. All the authors drafted and approved the final manuscript. 


\section{Funding}

This work was financially supported by projects from the National Transgenic Research Projects of China (2018ZX08020001) and the Key R\&D Program of Shaanxi Province (2018NY-055). The funding body played no role in the design of the study, the collection, analysis, or interpretation of data or the writing of the manuscript.

\section{Availability of data and materials}

All the supporting data are included within the article and its additional files.

\section{Ethics approval and consent to participate}

Not applicable.

\section{Consent for publication}

Not applicable.

\section{Competing interests}

The authors declare that they have no competing interests.

Received: 24 April 2019 Accepted: 3 February 2020

Published online: 11 February 2020

\section{References}

1. Becker H, Damgaard C, Karlsson B. Environmental variation for outcrossing in rapeseed (Brassica napus). Theore Appl Genet. 1992;84(3-4):303-6.

2. Frauen M, Noack J, Girke A, Paulmann W. Ten years experience of development and cultivation of winter oilseed rape hybrids in Europe based on the MSL system. In: Proceedings of 12 th international rapeseed congress, 26-30 march 2007, Wuhan, China; 2006.

3. Xia S, Wang Z, Zhang H, Hu K, Zhang Z, Qin M, Dun X, Yi B, Wen J, Ma C, Shen J, Fu T, Tu J. Altered transcription and neofunctionalization of duplicated genes rescue the harmful effects of a chimeric gene in Brassica napus. Plant Cell. 2016:28:2060-78.

4. Levings CS III. The Texas cytoplasm of maize: cytoplasmic male sterility and disease susceptibility. Science. 1990;250:942-7.

5. Chakrabarty SK, Maity A, Yadav JB. Influence of cyto-sterility sources of female line on seed quality of Indian mustard (Brassica juncea L. Czern \& Coss.) in relation to storage period. Plant Breed. 2015;134:333-7.

6. Dey SS, Bhatia R, Parkash C, Sharma S, Dabral M, Mishra V, Bhardwaj I, Sharma K, Kumar SV, Kumar R. Alteration in important quality traits and antioxidant activities in Brassica oleracea with Ogura cybrid cytoplasm. Plant Breed. 2017;136(3):400-9.

7. Lobos-Sujo V, Duncan R. Evaluation of the Rfo introgression following recombination and mutation. Saskatoon: Proceedings of 14th International Rapeseed Congress; 2015. Abstract 248

8. McVetty PBE. Cytoplasmic male sterility. In: Shivanna KR, Sawhney VK, editors. Pollen biotechnology for crop production and improvement. Cambridge: Cambridge University Press; 1997. p. 155-82.

9. Fu TD. Production and research of rapeseed in the People's Republic of China. Cruciferae Newsletter. 1981;6:6-7

10. Liu XQ, Liu ZQ, Yu CY, Dong JG, Hu SW, Xu AX. TGMS in rapeseed (Brassica napus) resulted in aberrant transcriptional regulation, asynchronous microsporocyte meiosis, defective tapetum, and fused sexine. Front Plant Sci. 2017:8:1268.

11. Fan ZX, Lei WX, Hong DF, He JP, Wan LL, Xu ZH, Liu PW, Yang GS Development and primary genetic analysis of a fertility temperaturesensitive polima cytoplasmic male sterility restorer in Brassica napus. Plant Breed. 2007;126:297-301

12. Pickett AA. Hybrid wheat - results and problems. In: Röbbelen $H$, Von G, Weber WE, editors. Advances in plant breeding. Plant Breed, vol. 15. Berlin: Paul Parey Scientific Publishers; 1993. p. 1-259.

13. Parodi PC, Gaju MA. Male sterility induced by the chemical hybridizing agent clofencet on wheat, Triticum aestivum and T. turgidum var. durum. Cien. Inv. Agr. 2009;36(2):267-76.

14. Banga SS, Labana KS. Production of $F_{1}$ hybrid using etherel induced male sterility in Indian mustard (B. juncea). J Agric Sci (Camb). 1983;101:453-5.

15. Guan $C Y$. Chemical induced male sterility and other ways of heterosis breeding. In: Fu TD, editor. Breeding and utilization of hybrid rapeseed. China: Hubei Science and Technology Press. Wuhan; 1995. p. 124-35.

16. Guan CY, Stringam GR. The effect of ZMA on inducing male sterility on spring canola. Cruciferae Newsletter. 1998;20:55-6.
17. Singh V, Chauhan SVS. Benzotriazole-a new chemical hybridizing agent for Brassica juncea L. J Cytol Genet. 2001;2:81-3.

18. Singh V, Chauhan SVS. Bud pollination and hybrid seed production in detergent-induced male sterile plants of Brassica juncea. Plant Breed. 2004; 122:421-5.

19. Yu C, Hu S, He P, Zhang C, Yu Y. Inducing male sterility in Brassica napus L. by a sulphonylurea herbicide, tribenuron-methyl. Plant Breed. 2006;125:61-4

20. Yu CY, Dong JG, Hu SW, He PR. Efficiency of a novel gametocide amidosulfuron on rapeseed (Brassica napus). Plant Breed. 2009;128:538-40.

21. Yu CY, Dong JG, Hu SW, Xu AX. Exposure to trace amounts of sulfonylurea herbicide tribenuron-methyl causes male sterility in 17 species or subspecies of cruciferous plants. BMC Plant Biol. 2017;17:95.

22. Duggleby RG, McCourt JA, Guddat LW. Structure and mechanism of inhibition of plant acetohydroxyacid synthase. Plant Physiol Biochem. 2008; 46:309-24.

23. Wall DA, Derksen DA, Friesen L. Canola (Brassica napus) response to simulated sprayer contamination with thifensulfuron and thifensulfuron: tribenuron (2:1). Weed Technol. 1995;9:468-76.

24. Londo JP, Mckinney J, Schwartz M, Bollman M, Sagers C, Watrud L. Sublethal glyphosate exposure alters flowering phenology and causes transient male-sterility in Brassica spp. BMC Plant Biol. 2014;14(1):70.

25. Zhao L, Jing X, Chen L, Liu Y, Su Y, Liu T, Gao C, Yi B, Wen J, Ma C, Tu J, Zou J, Fu T, Shen J. Tribenuron-methyl induces male sterility through antherspecific inhibition of acetolactate synthase leading to autophagic cell death Mol Plant. 2015;8:1710-24.

26. Liu XQ, Yu CY, Dong JG, Hu SW, Xu AX. Acetolactate synthase-inhibiting gametocide amidosulfuron causes chloroplast destruction, tissue autophagy, and elevation of ethylene release in rapeseed. Front Plant Sci. 2017:8:1625

27. Lian JL, Ren LS, Zhang C, Yu CY, Huang Z, Xu AX. How exposure to ALSinhibiting gametocide tribenuron-methyl induces male sterility in OSR. BMC Plant Biol. 2019;19:124

28. Li H, Li J, Zhao B, Wang J, Yi L, Liu C, Wu J, King GJ, Liu K. Generation and characterization of tribenuron-methyl herbicide-resistant rapeseed (Brasscia napus) for hybrid seed production using chemically induced male sterility. Theor Appl Genet. 2015;128:107-18.

29. Lv J, Huang Q, Sun Y, Qu G, Guo Y, Zhang X, Zhao H, Hu S. Male sterility of an AHAS-mutant induced by tribenuron-methyl solution correlated with the decrease of AHAS activity in Brassica napus L. Front Plant Sci. 2018;9:1014.

30. Hu ML, Pu HM, Zhang JF. Research advances of rapeseed germplasms with ALS-inhibiting herbicides resistances in China. Chinese J Oil Crop Sci. 2018; 40(5):679-86.

31. Praba ML, Thangaraj M. Effect of growth regulators and chemicals on pollen sterility in TGMS lines of rice. Plant Growth Regul. 2005;46:117-24.

32. Zhou YM, Bai HH. Identification and genetic studies of the inhibition of dominant male sterility in Brassica napus. Plant Breed. 1994;113:222-6.

33. Tang QY, Zhang CX. Data processing system (DPS) software with experimental design, statistical analysis and data mining developed for use in entomological research. Insect Sci. 2013;20(2):254-60.

\section{Publisher's Note}

Springer Nature remains neutral with regard to jurisdictional claims in published maps and institutional affiliations.

Ready to submit your research? Choose BMC and benefit from

- fast, convenient online submission

- thorough peer review by experienced researchers in your field

- rapid publication on acceptance

- support for research data, including large and complex data types

- gold Open Access which fosters wider collaboration and increased citations

- maximum visibility for your research: over $100 \mathrm{M}$ website views per year

At BMC, research is always in progress.

Learn more biomedcentral.com/submissions 